\title{
LEKSIKON PERALATAN RUMAH TANGGA BERBAHAN BAMBU DI KABUPATEN MAGETAN (KAJIAN ETNOLINGUISTIK)
}

\author{
Siti Komariyah
}

Balai Bahasa Jawa Timur, sitikomaria1421@gmail.com

\begin{abstract}
ABSTRAK
Penelitian ini dilatarbelakangi oleh pemanfaatan bambu di wilayah Kabupaten Magetan sebagai peralatan rumah tangga. Tujuan dari penelitian ini adalah 1) mengklasifikasikan dan mendeskripsikan leksikon peralatan rumah tangga berbahan bambu di Magetan; 2) mengungkapkan fungsi peralatan rumah tangga berbahan bambu di Magetan. Pengumpulan data dengan pengamatan dan wawancara dengan informan utama dan informan pendamping; Penelitian ini menggunakan pendekatan etnolingustik yang menelaan hubungan bahasa dan budaya terutama bagaimana bahasa itu digunakan sehari-hari sebagai alat komunikasi dalam suatu kelompok masyarakat. Perkembangan budaya mempengaruhi perkembangan leksikon yang berhubungan dengan budaya tersebut. Leksikon muncul seiring dengan kebutuhan manusia untuk mengidentifikasi hasil budaya yang ada. Leksikon peralatan rumah tangga berbahan bambu di Magetan relatif banyak dan beragam Dari hasil penelitian ini diperoleh sejumlah leksikon yang dapat dipilah menjadi empat kategori, yaitu (1) leksikon peralaran rumah tanga berbahan bambu yang berbentuk monomorfemis, (2) leksikon peralatan rumah tangga berbahan bambu yang berbentuk polimorfemis, (3) leksikon peralatan rumah tanga berbahan bambu yang berbentuk kata ulang, dan (4) leksikon berbahan bambu yang berbentuk frasa.
\end{abstract}

Kata Kunci: Leksikon, etnolinguistik, monomorfemis, polimorfemis

\section{PENDAHULUAN}

Perkembangan budaya mempengaruhi perkembangan leksikon atau istilah yang berhubungan dengan budaya tertentu. Leksikon muncul seiring dengan kebutuhan manusia untuk mengidentifikasi hasil budaya yang ada. Pemakaian leksikon terkait erat dengan berbagai macam hal yang ada dalam budaya masyarakat pengguna leksikon tersebut. Berkembangnya kebudayaan pada masyarakat tertentu dapat dilihat salah satunya dari perkembangan leksikon tentang budaya tersebut. Peralatan rumah tangga tradisional merupakan salah satu warisan budaya nenek moyang. Dengan semakin majunya perkembangan zaman, 
masyarakat kurang paham dengan peniggalan nenek moyang tersebut. Namun, peralatan tradisional yang sudah kuna masih tetap bertahan hidup dan masih banyak digunakan oleh sebagian masyarakat terutama di daerah pedesaan. Peralatan tradisional pada umumnya dipandang sebagai suatu benda yang dianggap 'kuna' dan tidak sesuai dengan perkembangan zaman. Pandangan umum ini memang sebagian benar karena bagian dari budaya modern menuntut adanya perubahan dari budaya terdahulu agar sesuai dengan prinsip keharmonisan hubungan sosial. Walaupun demikian, sebagian masyarakat menganggap hal yang berhubungan dengan tradisional adalah sebagai bentuk yang unik dan patut dijaga kelestariannya. Seiring dengan perkembangan teknologi akan mendesak unsurunsur tradisional yang berakibat timbulnya pergeseran nilai-nilai, arti dan fungsi dari suatu tradisi yang telah berkembang lama. Tradisi-tradisi lama tersebut banyak sudah tidak dilestarikan lagi sehingga akan hilang. Dengan adanya kemajuan dan perkembangan teknologi, pada umumnya masyarakat sekarang kurang memperhatikan nilai budaya yang terkandung dalam pola-pola tradisional atau bahkan mereka sudah melupakan dan menganggap tidak perlu karena sudah kuno. Nilai-nilai budaya yang merangkum konsep-konsep kepercayaan normanorma, keyakinan, pandangan hidup serta peraturan-peraturan yang telah menjadi milik suatu masyarakat dan telah dilakukan dalam pola pikir dan tingkah laku secara turun-temurun. Di Magetan, banyak daerah atau desa yang masyarakatnya terutama para ibu rumah tangga mencari penghasilan untuk memenuhi kebutuhan rumah tangga dengan membuat peralatan berbahan bambu. Selain itu, untuk mencukupi keperluan sehari-hari, masyarakat Magetan masih banyak yang menggunakan berbagai peralatan tradisional berbahan bambu. Alat-alat tersebut masing-masing mempunyai nama, makna dan fungsi sendiri-sendiri. Pada pengamatan dilapangan, hampir di seluruh daerah Magetan mengenal peralatan atau alat-alat dapur yang bersifat tradisional. Dalam menyebutkan nama-nama peralatan rumah tangga tradisional ada beberapa perbedaan meskipun benda tersebut memiliki fungsi sama.

Untuk lebih jelasnya berikut adalah contoh nama peralatan rumah tangga tradisional berbahan bambu yang dikenal oleh masyarakat Magetan. Peralatan rumah tangga tradisional yang terbuat dari bambu seperti antara lain bèsèk,cêthing, irig, kalo, tampah, tambir, tompo, cikrak, kukusan, tenggok, tenong, tumbu, dan lain-lain. Banyak masyarakat menggunakan peralatan rumah tangga terbuat dari bambu sebagai hiasan atau keunikan yang membuat suasana menjadi alami seperti di alam bambu. Contohnya peralatan rumah tangga yang 
terbuat dari bambu yaitu kukusan yang merupakan alat untuk mengukus akan tetapi pada zaman sekarang kukusan 'kukusan' bisa digunakan sebagai tempat lampu yang begitu unik. Sebagian masyarakat mengunakan peralatan rumah tangga yang bernuansa tradisional dan estetis. Hai ini tentu akan sangat berbeda dengan peralatan rumah tangga yang dibuat bernuansa penuh gaya dan modern. Fokus penelitian ini adalah bentuk dan makna peralatan rumah tangga tradisional berbahan bambu.

Alasan pemilihan kajian makna leksikal nama peralatan rumah tangga tradisional di Magetan kerena sangat menarik untuk dikaji Peralatan atau alat-alat dapur tradisional seperti tersebut di atas pada zaman sekarang masih banyak dipergunakan oleh masyarakat di pedesaan dan sebagian kecil masyarakat di perkotaan. Berdasarkan fakta yang ada di sekitar kita, maka peralatan rumah tangga tradisional di Magetan ini memiliki banyak sekali makna dan fungsi tergantung dengan alatnya itu sendiri.

Berdasarkan latar belakang di atas, masalah yang akan dikaji dalam penelitian ini adalah

1. Bagaimanakah bentuk leksikal peralatan rumah tangga tradisional berbahan bambu di Magetan?

2. Apakah fungsi peralatan rumah tangga tradisional berbahan bambu di Magetan?

Berdasarkan rumusan masalah di atas, tujuan penelitian ini adalah

1. mendeskripsikan bentuk leksikal peralatan rumah tangga tradisional berbahan bambu di Magetan

2. mendiskripsikan fungsi peralatan rumah tangga tradisional berbahan bambu di Magetan.

Linguistik kebudayaan atau etnolinguistik merupakan cabang linguistik yang dapat digunakan untuk menyelidiki hubungan antara bahasa dan budaya masyarakat di pedesaan atau masyarakat yang belum memiliki tulisan. Namun definisi ini meluas seiring dengan perkembangan zaman, semakin sedikit pula jumlah masyarakat pedesaan yang belum mempunyai tulisan (Kridalaksana, 2001: 52). Menurut Baehaqie (2013: 14) etnolinguistik secara terminologi 
merupakan ilmu perihal bahasa yang berkitan dengan masalah kebudayaan suatu bangsa dan masyarakat penduduk suatu daerah di seluruh dunia secara komparatif (2013: 14). Koentjaraningrat (1983:182) mengatakan bahwa kebudayaan pada umumnya diwariskan secara lebih seksama melalui bahasa; artinya bahasa merupakan wahana utama bagi pewarisan, sekaligus pengembangan kebudayaan.. Sedangkan Duranti (1997:27) mengatakan bahwa mendeskripsikan suatu budaya sama halnya dengan mendeskripsikan bahasa. Wierzbicka (1991) juga menelaah hubungan antara bahasa dan kebudayaan dalam konteks wacana kebudayaan yang merupakan pendekatan baru dalam studi komunikasi lintas-budaya. Anggapan yang dikemukakan oleh Wierzbicka merupakan gambaran nyata mengenai hubungan empirik dan teoritik antara bahasa dan kebudayaan yang berpatokan pada tiga kata kunci, yakni: (1) masyarakat/ guyub, baik guyub tutur maupun guyub budaya; (2) cara berinteraksi; dan (3) nilai budaya. Guyub berbeda memperlihatkan cara berinteraksi yang berbeda, yang juga memperlihatkan nilai budaya yang berbeda.

Hubungan antara bahasa dan kebudayaan dimunculkan juga secara konseptual-teroretis, yang tidak hanya dinamai secara bervariasi, tetapi terutama dimaknai secara berbeda. Cardona, Duranti (1997:2) menjelaskan bahwa istilah ethnolinguistics dalam bahasa Inggris sepadan dengan istilah étnolinguistica dalam bahasa Rusia, ethnolinguistique dalam bahasa Perancis, ethnolinguistik dalam bahasa Jerman, etnolingüística dalam bahasa Spanyol, dan etnolingiuística dalam bahasa Portugis. Uraian ini menunjukkan bahwa istilah etnolinguistik pernah sangat populer di Eropa, yang ketika itu di Amerika dikenal dengan istilah antropologi linguistik.

Istilah yang belakangan ini banyak digunakan mengacu pada bidang ilmu interdisipliner antara bahasa dan kebudayaan, yakni: antropologi linguistik (linguistic anthropology) Tidak terdapat penjelasan yang lebih rinci mengenai perbedaan cakupan dari kedua istilah untuk bidang ilmu interdisipliner tersebut. Hanya ada keterangan singkat yang dikemukakan oleh Duranti (1997:1-2) yang mengatakan bahwa istilah antropologi linguistik digunakan dengan pengertian yang sama dengan istilah linguistik antropologi.

Konsep linguistik kebudayaan telah digunakan oleh Alisjahbana (1977:290) yang mengatakan bahwa bahasa tidak hanya sekedar alat komunikasi. Alisjahbana memperlihatkan keterkaitan bahasa dan kebudayaan dengan mengatakan bahwa bahasa merupakan penjelmaan budaya. Linguistik kebudayaan sesungguhnya adalah bidang ilmu interdisipliner yang mengkaji hubungan kovariatif antara struktur bahasa dengan kebudayaan suatu masyarakat (Mbete, 
2004:18 - 25). Jika dikaitkan dengan pendapat Wierzbicka (1994:1), maka linguistik kebudayaan terkait erat dengan pertanyaan: "Mengapa setiap kelompok etnik mengggunakan bahasa ataupun ragam yang berbeda, dan dengan cara yang berbeda?" Pertanyaan ini bermuara pada upaya untuk menjelaskan alasan pemilihan bentuk, jenis (genre), ragam ataupun diksi pada sebuah tuturan oleh satu kelompok etnik. Penjelasan itu terkait dengan pemaknaan sebuah tuturan, khususnya terkait dengan tuturan ritual sehubungan dengan padangan penuturnya terhadap dunia (Palmer, 1996:113).

Konsep linguistik kebudayaan digunakan pula oleh Palmer (1996) sebagai cultural linguistics. Palmer (1996:36) mengemukakan bahwa linguistik kebudayaan adalah sebuah nama yang cenderung mengandung pengertian luas dalam kaitan dengan bahasa dan kebudayaan.

Metode pengumpulan data yang digunakan dalam penelitian ini adalah metode simak, cakap, dengan teknik catat. Metode simak adalah kegiatan yang dilakukan dengan menyimak penggunaan bahasa (Sudaryanto 1993: 133). Metode cakap beserta teknik-tekniknya akan digunakan untuk memperoleh data dari lapangan. Metode cakap iui ditempuh dengan mengadakan percakapan antara peneliti dengan informan. Dengan adanya kontak antara peneliti dengan informan itu memungkinkan kajian etnolinguistik berjalan. Yang dimaksud dengan informan di sini ialah informan kunci dan informan tambahan yang berkemampuan memberi informasi kebahasaan kepada peneliti, khususnya mengenai istilah alat-alat rumah tangga tradisional sebagai objek data penelitian. Teknik dasar yang digunakan adalah teknik pancing, karena penyebutan istilah alat-alat rumah tangga yang dikenal informan berlangsung setelah adanya stimulasi (pancingan) dari peneliti dan informan menyebutkan satu per satu data yang dibutuhkan. Teknik lanjutannya dengan teknik cakap semuka, teknik cakap semuka, teknik cakap, teknik pemotretan, dan teknik catat. Di samping itu, untuk mendapatkan data yang memadai perlu dilakukan dengan teknik wawancara mendalam (indept interviewing). Metode analisis menggunakan metode deskriptif. data ini menyangkut analisis penentuan istilah alat-alat rumah tangga yang tradisional maupun modern. Penentuan perkembangan istilah alat-alat rumah tangga dari yang tradisional ke yang modern berdasarkan kesamaan fungsinya, penentuan latar belakang budaya yang mempengaruhi perkembangan tersebut. 


\section{PEMBAHASAN}

Berdasarkan pengamatan dan hasil data kebahasaan di lapangan, diperoleh data-data berupa leksikon peralatan rumah tangga berbahan bambu di Kabupaten Magetan. Apabila dilihat dari sejumlah leksikon tersebut dapat dipilah menjadi empat kategori, yaitu (1) leksikon peralaran rumah tanga berbahan bambu yang berbentuk monomorfemis, (2) leksikon peralatan rumah tangga berbahan bambu yang berbentuk polimorfemis, dan (3) leksikon peralatan rumah tanga berbahan bambu yang berbentuk kata ulang, dan (4) leksikon berbahan bambu yang berbentuk frasa.

Deskripsi Bentuk dan Makna Leksikon Peralatan Rumah Tangga Berbahan Bambu

Dari data yang diperoleh dalam penelitian ini adalah leksikon peralatan rumah tangga berbahan bambu terdapat empat kategori bentuk kata, yaitu berstruktur monomorfemis, polimorfemis, bentuk kata ulang, dan frasa seperti pada data berikut.

Nama Peralatan yang Termasuk Kata Monomorfemis

Berdasarkan data yang ada, leksikon yang berkaitan dengan peralatan rumah tangga tradisional berbahan dasar bambu masih cukup banyak digunakan oleh masyarakat di wilayah Magetan. Dari pengamatan terdapat tiga puluh leksikon peralatan rumah tangga berbahan bambu yang berbentuk kata monomorfemis sepertipada tabel berikut.

Tabel 1: Leksikon Peralatan Rumah Tangga berbentuk Monomorfemis

\begin{tabular}{|l|l|l|l|}
\hline No. & \multicolumn{1}{|c|}{ Leksikon } & \multicolumn{1}{|c|}{ Bentuk } & \multicolumn{1}{c|}{ Fungsi } \\
\hline 1. & $\begin{array}{l}\text { Angkrik } \\
\text { [aGkri?] }\end{array}$ & $\begin{array}{l}\text { Rak bersusun yang } \\
\text { terbuat dari bambu } \\
\text { dengan tiang empat } \\
\text { buah berbentuk } \\
\text { menyerupai almari } \\
\text { tanpa tutup }\end{array}$ & $\begin{array}{l}\text { Rak ini berfungsi untuk } \\
\text { meletakkan perkakas dapur } \\
\text { seperti piring gelas, } \\
\text { mangkok, panci dan } \\
\text { sebagainya. }\end{array}$ \\
\hline
\end{tabular}

6| http://journal.unesa.ac.id/index.php/paramasastra 


\begin{tabular}{|c|c|c|c|}
\hline 2. & $\begin{array}{l}\text { Besek } \\
\text { [bEsE?] }\end{array}$ & $\begin{array}{l}\text { Anyaman bambu yang } \\
\text { disisir tipis berbentuk } \\
\text { persegi empat }\end{array}$ & $\begin{array}{l}\text { Fungsi besek biasanya } \\
\text { digunakan untuk wadah nasi } \\
\text { selamatan, tape, jajanan dan } \\
\text { sebagainya. Untuk wadah } \\
\text { biasanya besek digunakan } \\
\text { sepasang dengan tutupnya. }\end{array}$ \\
\hline 3. & Capil [capIl] & $\begin{array}{l}\text { Topi berbentuk } \\
\text { kerucut dengan bagian } \\
\text { bawah lebar, yang dari } \\
\text { bambu yang dianyam } \\
\text { kecil-kecil.Anyaman } \\
\text { capil terdiri atas } 3 \\
\text { bagian. Bagian dalam } \\
\text { dengan anyaman tipis } \\
\text { dan halus karena } \\
\text { langsung bersentuhan } \\
\text { langsung dengan } \\
\text { kepala ketika dipakai. } \\
\text { Bagian tengah } \\
\text { anyaman bambunya } \\
\text { lebih tebal dan kaku } \\
\text { yang berfungsi } \\
\text { pembentuk dan } \\
\text { penahan kerucut } \\
\text { supaya kaku dan } \\
\text { bentuknya bagus dan } \\
\text { lebih tahan jika } \\
\text { terkena air hujan. } \\
\text { Sedangkan bagian } \\
\text { terluar anyaman } \\
\text { bambu mengunakan } \\
\text { bahan kulit bambu } \\
\text { yang sudah dikerik } \\
\text { sehingga }\end{array}$ & $\begin{array}{l}\text { Fungsi capil ini dipakai } \\
\text { sebagai pelindung kepala dari } \\
\text { sengatan matahari. Pada } \\
\text { umumnya capil ini digunakan } \\
\text { para petani ketika bekerja di } \\
\text { sawah untuk pelindung } \\
\text { kepala dari terik matahari dan } \\
\text { hujan. }\end{array}$ \\
\hline
\end{tabular}




\begin{tabular}{|c|c|c|c|}
\hline & & permukaannya halus. & \\
\hline 4. & $\begin{array}{l}\text { Cething } \\
\text { [c|.tIG] }\end{array}$ & $\begin{array}{l}\text { Bakul berbentuk kotak } \\
\text { berkaki yang terbuat } \\
\text { dari anyaman bambu. }\end{array}$ & $\begin{array}{l}\text { Fungsi cething digunakan } \\
\text { untuk wadah nasi. Pada } \\
\text { umumnya masyarakat di } \\
\text { pedesaan lebih suka } \\
\text { mengunakan cething } \\
\text { daripada wadah nasi modern. }\end{array}$ \\
\hline 5. & $\begin{array}{l}\text { Cikrak } \\
\text { [cikra?] }\end{array}$ & $\begin{array}{l}\text { Anyaman bambu } \\
\text { berbentuk pipih } \\
\text { melengkung. }\end{array}$ & $\begin{array}{l}\text { Fungsi cikrak ini digunakan } \\
\text { untuk mengeruk sampah }\end{array}$ \\
\hline 6. & $\begin{array}{l}\text { Encek } \\
{[\text { EncE?] }}\end{array}$ & $\begin{array}{l}\text { Anyaman bambu } \\
\text { berbentuk persegi } \\
\text { empat dengan ukuran } \\
\text { kurang lebih } 40 \mathrm{~cm}\end{array}$ & $\begin{array}{l}\text { Fungsi encek biasanya } \\
\text { digunakan untuk alas sesaji } \\
\text { atau makanan untuk } \\
\text { selamatan yang dilakukan di } \\
\text { sawah untuk prosesi sebelum } \\
\text { memulai panen padi. }\end{array}$ \\
\hline 7. & Galar [galar] & $\begin{array}{l}\text { Bambu yang dibelah } \\
\text { kecil-kecil dengan } \\
\text { ukuran panjang dua } \\
\text { meter. }\end{array}$ & $\begin{array}{l}\text { Fungsi galar ini digunakan } \\
\text { untuk alas tikar atau kasur } \\
\text { pada tempat tidur bambu atau } \\
\text { kayu. }\end{array}$ \\
\hline 8. & Ilir [ilIr] & $\begin{array}{l}\text { Anyaman bambu tipis- } \\
\text { tipis berbentuk segi } \\
\text { empat atau segi lima } \\
\text { dengan ukuran besar }\end{array}$ & $\begin{array}{l}\text { Ilir digunakan untuk kipas, } \\
\text { misalnya mengipasi bara } \\
\text { arang untuk membakar sate, } \\
\text { ikan, dll. }\end{array}$ \\
\hline
\end{tabular}




\begin{tabular}{|c|c|c|c|}
\hline 9. & Irig [irIg] & $\begin{array}{l}\text { Anyaman bambu tipis, } \\
\text { agak renggang } \\
\text { berbentuk bulat, pada } \\
\text { bagian tepi diberi } \\
\text { belahan bambu } \\
\text { berbentuk tipis yang } \\
\text { dipasang melingkar. }\end{array}$ & $\begin{array}{l}\text { Fungsi irig digunakan untuk } \\
\text { mengayak pasir. }\end{array}$ \\
\hline 10. & $\begin{array}{l}\text { Kabruk } \\
{[\text { kabrU?] }}\end{array}$ & $\begin{array}{l}\text { Anyaman bambu } \\
\text { berbentuk kerucut } \\
\text { pendek melebar, } \\
\text { anyaman pada bagian } \\
\text { bawah agak renggang } \\
\text { dibandingkan dengan } \\
\text { bagian atas. }\end{array}$ & $\begin{array}{l}\text { Fungsi kabruk digunakan } \\
\text { untuk mengukus beras } \\
\text { sebelum dimasukkan ke } \\
\text { dalam air panas untuk direbus } \\
\text { setengah matang. }\end{array}$ \\
\hline 11. & Kalo [kalo] & $\begin{array}{l}\text { Anyaman berbentuk } \\
\text { persegi empat dengan } \\
\text { diberi pinggiran } \\
\text { berupa belahan bambu } \\
\text { tipis melebar. }\end{array}$ & $\begin{array}{l}\text { Fungsi kalo ini digunakan } \\
\text { untuk menyaring kelapa parut } \\
\text { ketika diambil santannya. }\end{array}$ \\
\hline 12. & $\begin{array}{l}\text { Kepang } \\
{[\text { kepaG] }}\end{array}$ & $\begin{array}{l}\text { Anyaman bambu } \\
\text { tipis-tipis menyerupai } \\
\text { tikar. }\end{array}$ & $\begin{array}{l}\text { Fungi kepang biasanya } \\
\text { digunakan untuk alas } \\
\text { menjemur padi. }\end{array}$ \\
\hline 13. & $\begin{array}{l}\text { Kreneng } \\
{[\mathrm{kr}|\mathrm{n}| \mathrm{G}]}\end{array}$ & $\begin{array}{l}\text { Keranjang bambu } \\
\text { kecil berbentuk segi } \\
\text { empat dengan } \\
\text { anyaman di bagian } \\
\text { bawah lebih renggang } \\
\text { daripada daripada } \\
\text { bagian atas. }\end{array}$ & $\begin{array}{l}\text { Kreneng ini biasanya } \\
\text { berfungsi untuk tempat } \\
\text { mencuci sayur yang akan } \\
\text { diolah. }\end{array}$ \\
\hline
\end{tabular}




\begin{tabular}{|c|c|c|c|}
\hline 14. & $\begin{array}{l}\text { Krenjang } \\
{[\mathrm{kr} \mid \mathrm{njaG}]}\end{array}$ & $\begin{array}{l}\text { Keranjang bambu } \\
\text { berbentuk segi empat } \\
\text { setinggi kurang lebih } \\
65 \mathrm{~cm} \text {. Anyamannya } \\
\text { cukup rapat. }\end{array}$ & $\begin{array}{l}\text { Krenjang ini biasanya } \\
\text { digunakan oleh penyabit } \\
\text { rumput untuk wadah rumput } \\
\text {.yang diperolehnya,. Selain } \\
\text { itu krenjang juga digunakan } \\
\text { untuk wadah ketela rambat, } \\
\text { kentang, wortel dan lain-lain } \\
\text { saat para petani membawa } \\
\text { hasil panenan mereka dari } \\
\text { sawah. }\end{array}$ \\
\hline 15. & $\begin{array}{l}\text { Pogo } \\
{[\mathrm{pOgO}]}\end{array}$ & $\begin{array}{l}\text { Anyaman bambu } \\
\text { dengan bentuk } \\
\text { menyerupai papan. } \\
\text { Pogo pada umumnya } \\
\text { dipasang di atas } \\
\text { tungku di dapur } \\
\text { dengan tali penahan } \\
\text { yang dipasang ke kayu } \\
\text { di bawah genteng }\end{array}$ & $\begin{array}{l}\text { pada umumnya berfungsi } \\
\text { untuk meletakkan makanan } \\
\text { atau bahan makanan }\end{array}$ \\
\hline 16. & Senik [s|nI?] & $\begin{array}{l}\text { Keranjang dengan } \\
\text { bahan bambu yang } \\
\text { sudah dibelah tipis- } \\
\text { tipis berbentuk kotak } \\
\text { dengan diameter } 49 \mathrm{~cm} \\
\text { atau lebih }\end{array}$ & $\begin{array}{l}\text { senik berfungsi utntuk wadah } \\
\text { barang para pembeli atau } \\
\text { pedagang di pasar. }\end{array}$ \\
\hline 17. & $\begin{array}{l}\text { Serok } \\
\text { [serO?] }\end{array}$ & $\begin{array}{l}\text { Anyaman bambu } \\
\text { berbentuk menyerupai } \\
\text { lingkaran cekung } \\
\text { dengan pegangan } \\
\text { kurang lebih sepanjang } \\
30 \mathrm{~cm}\end{array}$ & $\begin{array}{l}\text { Serok berfungsi untuk } \\
\text { mengambil gorengan dari } \\
\text { wajan. }\end{array}$ \\
\hline
\end{tabular}




\begin{tabular}{|c|c|c|c|}
\hline 18. & $\begin{array}{l}\text { Songgong } \\
\text { [sOGgOG] }\end{array}$ & $\begin{array}{l}\text { Anyaman bambu } \\
\text { berbentuk menyerupai } \\
\text { jam pasir }\end{array}$ & $\begin{array}{l}\text { Songgong berfungsi sebagai } \\
\text { alas untuk meletakkan alat } \\
\text { pengukus nasi, yaitu kukusan } \\
\text { atau kabruk di dapur. }\end{array}$ \\
\hline 19. & $\begin{array}{l}\text { Tampah } \\
\text { [tampah] }\end{array}$ & $\begin{array}{l}\text { Anyaman bambu } \\
\text { berbentuk bulat } \\
\text { dengan pinggiran } \\
\text { bambu tipis di } \\
\text { sekelilingnya, } \\
\text { menyerupai nampan } \\
\text { dengan diameter } \\
\text { kurang lebih } 60 \mathrm{~cm}\end{array}$ & $\begin{array}{l}\text { Tampah befungsi untuk } \\
\text { menampi/membersihkan } \\
\text { beras. Selain itu bisa juga } \\
\text { digunakan untuk alas/ wadah } \\
\text { menata tumpeng beserta lauk } \\
\text { pauknya }\end{array}$ \\
\hline 20. & $\begin{array}{l}\text { Tebok } \\
\text { [tebO?] }\end{array}$ & $\begin{array}{l}\text { Anyaman bambu } \\
\text { berbentuk bulat } \\
\text { dengan pinggiran } \\
\text { bambu tipis di } \\
\text { sekelilingnya, } \\
\text { menyerupai nampan } \\
\text { dengan diameter } \\
\text { kurang lebih } 35 \mathrm{~cm} .\end{array}$ & $\begin{array}{l}\text { Tebok berbentuk sama } \\
\text { dengan tampah akan tetapi } \\
\text { memiliki ukuran lebih kecil. }\end{array}$ \\
\hline 21. & $\begin{array}{l}\text { Tenggok } \\
\text { [teGgO?] }\end{array}$ & $\begin{array}{l}\text { Anyaman bambu } \\
\text { berbentuk keranjang } \\
\text { kotak berukuran kecil, } \\
\text { dengan anyaman yang } \\
\text { cukup rapat. }\end{array}$ & $\begin{array}{l}\text { Pada umumnya tenggok } \\
\text { digunakan untuk wadah nasi, } \\
\text { atau wadah untuk mencuci } \\
\text { beras. }\end{array}$ \\
\hline 22. & $\begin{array}{l}\text { Tenong } \\
\text { [tenOG] }\end{array}$ & $\begin{array}{l}\text { Anyaman bambu } \\
\text { berbentuk oval, terdiri } \\
\text { atas dua bagian yaitu } \\
\text { bagian bawah dan } \\
\text { bagian atas untuk }\end{array}$ & $\begin{array}{l}\text { Tenong biasanya berfungsi } \\
\text { untuk tempat hantaran berupa } \\
\text { kue-kue dalam prosesi } \\
\text { lamaran pernikahan. }\end{array}$ \\
\hline
\end{tabular}




\begin{tabular}{|c|c|c|c|}
\hline & & tutup. & \\
\hline 23. & $\begin{array}{l}\text { Tepas } \\
\text { [tepas] }\end{array}$ & $\begin{array}{l}\text { Anyaman bambu tipis } \\
\text { berbentuk oval atau } \\
\text { prisma dengan pegan }\end{array}$ & yang berfungsi untuk kipas. \\
\hline 24. & $\begin{array}{l}\text { Tomblok } \\
\text { [tOmblO?] }\end{array}$ & $\begin{array}{l}\text { Keranjang dengan } \\
\text { bahan bambu yang } \\
\text { dianyam tidak terlalu } \\
\text { rapat. }\end{array}$ & $\begin{array}{l}\text { Fungsi tomblok biasanya } \\
\text { digunakan para petani untuk } \\
\text { tempat membawa sayur hasil } \\
\text { panenan dari sawah. }\end{array}$ \\
\hline 25. & $\begin{array}{l}\text { Trompo } \\
{[\text { trOmpO] }}\end{array}$ & $\begin{array}{l}\text { Anyaman dari kulit } \\
\text { bambu tipis, berbentuk } \\
\text { menyerupai tikar. } \\
\text { Bahan trompo ini } \\
\text { terbuat dari kulit } \\
\text { bamboo }\end{array}$ & $\begin{array}{l}\text { Trompo berfungsi untuk } \\
\text { plafon rumah }\end{array}$ \\
\hline 26. & $\begin{array}{l}\text { Tumbu } \\
\text { [tumbu] }\end{array}$ & $\begin{array}{l}\text { Anyaman bambu } \\
\text { berbentuk keranjang } \\
\text { menyerupai tenggok } \\
\text { dengan anyaman di } \\
\text { bagian atas rapat-rapat } \\
\text { tetapi di bagian bahaw } \\
\text { jarang-jarang. }\end{array}$ & $\begin{array}{llr}\text { Tumbu ini } & \text { biasanya } \\
\text { digunakan untuk } & \text { wadah } \\
\text { mencuci sayuran. } & \end{array}$ \\
\hline 27. & $\begin{array}{l}\text { Tambir } \\
\text { [tambIr] }\end{array}$ & $\begin{array}{l}\text { Tambir adalah tampah } \\
\text { dengan pinggiran tipis. } \\
\text { Anyaman bambu tipis } \\
\text { berbentuk bulat seperti } \\
\text { nampan dengan diberi } \\
\text { pinggiran belahan } \\
\text { bambu kecil }\end{array}$ & $\begin{array}{l}\text { Tambir ini biasanya } \\
\text { digunakan untuk alas } \\
\text { meletakkan tumpeng beserta } \\
\text { lauk-pauknya. }\end{array}$ \\
\hline
\end{tabular}

12| http://journal.unesa.ac.id/index.php/paramasastra 


\begin{tabular}{|l|l|l|l|}
\hline 28. & $\begin{array}{l}\text { Tembor } \\
\text { tembOr] }\end{array}$ & $\begin{array}{l}\text { Anyaman bambu } \\
\text { berbentuk menyerupai } \\
\text { bakul berukuran besar } \\
\text { dengan diameter kira- } \\
\text { kira } 50-60 \mathrm{~cm} .\end{array}$ & $\begin{array}{l}\text { Fungsi tembor digunakan utk } \\
\text { mencuci/ proses } \\
\text { membersihkan kulit kedelai } \\
\text { yang sudah direbus untuk } \\
\text { bahan pembuatan tempe } \\
\text { tempe. }\end{array}$ \\
\hline 29. & $\begin{array}{l}\text { Widik } \\
\text { [widI?] }\end{array}$ & $\begin{array}{l}\text { Anyaman bambu } \\
\text { berbentuk seperti } \\
\text { papan persegi panjang }\end{array}$ & $\begin{array}{l}\text { Widik biasanya digunakan } \\
\text { untuk alas menjemur } \\
\text { makanan tradisional seperti } \\
\text { rengginang, krupuk puli, dll. }\end{array}$ \\
\hline 30. & $\begin{array}{l}\text { Amben } \\
\text { (ambEn) }\end{array}$ & $\begin{array}{l}\text { Tempat tidur yang } \\
\text { terbuat bambu, } \\
\text { biasanya } \\
\text { menggunakan jenis } \\
\text { bambu tertentu yaitu } \\
\text { bambu petung. }\end{array}$ & Untuk tempat tidur \\
\hline
\end{tabular}

Pada tabel di atas, terdapat tiga puluh leksikon peralatan rumah tanga berbahan bambu yang berbentuk monomorfemis, yaitu angkrik, besek, capil, cething, cikrak, encek, galar, ilir, irik, kabruk, kalo, kepang, kreneng, krenjang, pogo, senik, serok, songong, tampah, tebok, tenggok, tenong, tepas, tomblok, trompo, tambir, tembor, widik, dan amben. Leksikon tersebut masih banyak digunakan dalam kehidupan sehari-hari masyarakat di Kabupaten Magetan, terutama masyarakat yang tinggal di pedesaan. Leksikon untuk mengungkap atau yang berhubungan dengan peralatan rumah tangga tersebut cukup memperkaya khasanah bahasa, khususnya yang berhubungan dengan peralatan berbahan bambu. Dari tiga puluh leksikon berbentuk frasa tersebut semua merupakan peninggalan budaya lama yang sudah ada sejak dahulu namun peralatan rumah 
tangga tradisional berbahan bambu tersebut masih terpelihara sampai sekarang dan tidak terpengaruh oleh budaya modern meskipun masyarakat pengguna peralatan tradisional tersebut juga menggunakan peralatan modern.

Nama Peralatan yang Termasuk Kata Polimorfemis.

Dari pengamatan dan hasil data di lapangan, terdapat peralatan tradisional berbahan bambu termasuk kata polimorfemis Berdasarkan data yang diperoleh, terdapat enam leksikon peralatan rumah tangga berbahan bambu yang berbentuk kata polimorfemis seperti kukusan, kentongan, kurungan, keregan, pikulan, dan planggrangan seperti pada tabel berikut

Tabel 2: Leksikon Peralatan Rumah Tangga berbentuk Poliomorfemis

\begin{tabular}{|l|l|l|l|}
\hline No. & Leksikon & Bentuk & Makna \\
\hline 1. & $\begin{array}{l}\text { Kukusan } \\
{[\text { kukusan }]}\end{array}$ & $\begin{array}{l}\text { Anyaman bambu tipis } \\
\text { berbentuk kerucut }\end{array}$ & $\begin{array}{l}\text { berfungsi sebagai wadah } \\
\text { untuk mengukus beras yang } \\
\text { telah direbus setengah } \\
\text { matang. Selain itu, kukusan } \\
\text { bisa juga digunakan untuk } \\
\text { cetakan tumpeng. }\end{array}$ \\
\hline 2. & $\begin{array}{l}\text { Kentongan } \\
{[\mathrm{k} \mid \text { ntOGan }]}\end{array}$ & $\begin{array}{l}\text { Bagian pangkal bambu } \\
\text { yang diberi lubang, } \\
\text { jika dipukul } \\
\text { mengeluarkan bunyi } \\
\text { khas }\end{array}$ & $\begin{array}{l}\text { berfungsi sebagai alat untuk } \\
\text { berkomunikasi/ } \\
\text { memberikan pengumuman } \\
\text { kepada warga kampung } \\
\text { untuk berkumpul misalnya } \\
\text { kerja bakti, pengumuman } \\
\text { adanya bencana, pencuri } \\
\text { dll. }\end{array}$ \\
\hline
\end{tabular}

14| http://journal.unesa.ac.id/index.php/paramasastra 


\begin{tabular}{|l|l|l|l|}
\hline 3. & $\begin{array}{l}\text { Kurungan } \\
\text { [kuruGan }]\end{array}$ & $\begin{array}{l}\text { Bambu yang dianyam } \\
\text { jarang-jarang } \\
\text { bentuknya menyerupai } \\
\text { tudung saji besar. }\end{array}$ & $\begin{array}{l}\text { Fungsi kurungan biasanya } \\
\text { digunakan sebagai alat } \\
\text { untuk mengurung ayam }\end{array}$ \\
\hline 4. & $\begin{array}{l}\text { Keregan } \\
\text { [kErEgan }]\end{array}$ & $\begin{array}{l}\text { Anyaman bambu tipis } \\
\text { jarang-jarang, } \\
\text { berbentuk persegi } \\
\text { empat dengan } \\
\text { pegangan di dua } \\
\text { sisinya. }\end{array}$ & $\begin{array}{l}\text { Keregan berfungsi untuk } \\
\text { mengayak pasir. }\end{array}$ \\
\hline 5. & $\begin{array}{l}\text { Pikulan } \\
\text { [pikulan] }\end{array}$ & $\begin{array}{l}\text { Belahan bambu } \\
\text { memanjang sekitar 1 } \\
\text { m }\end{array}$ & $\begin{array}{l}\text { Pikulan berfungsi untuk } \\
\text { membawa keranjang } \\
\text { dengan menempatkan dua } \\
\text { keranjang di kedua } \\
\text { ujungnya. }\end{array}$ \\
\hline 6. & $\begin{array}{l}\text { Planggrangan } \\
\text { [planGgraGan] }\end{array}$ & $\begin{array}{l}\text { Rak gantung dengan } \\
\text { bahan bambu }\end{array}$ & $\begin{array}{l}\text { untuk menempatkan piring } \\
\text { atau panci-panci di dapur }\end{array}$ \\
\hline
\end{tabular}

Pada tabel di atas, terdapat leksikon peralatan rumah tanga berbahan bambu yang berbentuk polimorfemis, yaitu kukusan, kentongan, kurungan, keregan, pikulan, dan planggrangan. Leksikon tersebut masih banyak digunakan dalam kehidupan sehari-hari masyarakat di Kabupaten Magetan, terutama masyarakat yang tinggal di pedesaan. Leksikon untuk mengungkap atau yang berhubungan dengan peralatan rumah tanga tersebut cukup memperkaya khasanah bahasa, khususnya yang berhubungan dengan peralatan berbahan bambu. 
Leksikon Peralatan Rumah Tangga berbentuk kata ulang

Selain leksikon berbentuk monomorfemis dan polimorfemis ditemukan juga leksikon peralatan rumah tangga berbahan bambu yang berbentuk kata ulang.

Berdasarkan data yang diperoleh di lapangan, leksikon peralatan rumah tangga berbahan bambu yang berbentuk kata ulang seperti berikut

1. Uleg-uleg [ul|g-ul|g]

Uleg-uleg adalah bagian pangkal bambu yang dibentuk melengkung dengan pegangan. Pada umumya bambu yang digunakan untuk membuat uleg-uleg tersebutber berasal dari pangkal bambu dengan jenis tertentu yaitu bambu ori atau petung. Uleg-uleg berfungsi untuk menghaluskan bumbu dapur.

Leksikon Peralatan Rumah Tangga yang berbentuk frasa

Berdasarkan data yang diperoleh di lapangan, selain leksikon berbentuk monomoefemis, polimorfemis, dan kata ulang, ditemukan juga leksikon peralatan rumah tangga berbahan bambu yang berbentuk frasa. Leksikon berbentuk frasa tersebut adalah besek cebek, besek ros, besek sabun, besek ros, besek gedhe, irik kalo, kursi petung, tudung saji, kranjang buah, kranjang pincuk, kranjang koran, kranjang jajan, kranjang tisu, kranjang blonjo, dan kranjang sampah seperti yang terdapat pada data dalam tabel berikut.

Tabel 3. Leksikon peralatan Rumah Tangga yang berbentuk frasa

\begin{tabular}{|l|l|l|l|}
\hline No. & Leksikon & \multicolumn{1}{|c|}{ Bentuk } & \multicolumn{1}{c|}{ Fungsi } \\
\hline 1. & $\begin{array}{l}\text { Besek cebek } \\
{[\mathrm{bEsE?}} \\
\text { cEbE?] }\end{array}$ & $\begin{array}{l}\text { Anyaman bambu } \\
\text { berbentuk kotak kecil } \\
\text { kira-kira berukuran 10cm }\end{array}$ & $\begin{array}{l}\text { untuk tempat berkat } \\
\text { selamatan, tempat tape, } \\
\text { tempat jajanan tradisonal } \\
\text { dll. }\end{array}$ \\
\hline 2. & $\begin{array}{l}\text { Besek sabun } \\
\text { [bEsE? } \\
\text { sabUn] }\end{array}$ & $\begin{array}{l}\text { Anyaman bambu } \\
\text { berbentuk persegi } \\
\text { panjang, dengan ukuran } \\
\text { sedang, digunakan } \\
\text { sepasang dengan }\end{array}$ & $\begin{array}{l}\text { untuk tempat berkat } \\
\text { selamatan, tempat jajanan } \\
\text { tradisonal, lempeng (krupuk } \\
\text { beras) dll }\end{array}$ \\
\hline
\end{tabular}

16| http://journal.unesa.ac.id/index.php/paramasastra 


\begin{tabular}{|c|c|c|c|}
\hline & & tutupnya & \\
\hline 3. & $\begin{array}{l}\text { Besek Ros } \\
\text { [ bEsE? ros] }\end{array}$ & $\begin{array}{l}\text { Anyaman bambu } \\
\text { berbentuk persegi } \\
\text { panjang, dengan ukuran } \\
\text { besar, digunakan } \\
\text { sepasang dengan } \\
\text { tutupnya }\end{array}$ & $\begin{array}{l}\text { untuk tempat tempat } \\
\text { jajanan tradisonal, lempeng } \\
\text { (krupuk beras) }\end{array}$ \\
\hline 4. & $\begin{array}{l}\text { Besek gedhe } \\
{[\mathrm{bEsE} ?} \\
\mathrm{g} \mid \mathrm{d}] \mathrm{e}]\end{array}$ & $\begin{array}{l}\text { Anyaman bambu } \\
\text { berbentuk persegi empat } \\
\text { besar, dg ukuran kurang } \\
\text { lebih } 50 \mathrm{~cm} \text {, digunakan } \\
\text { sepasang dengan } \\
\text { tutupnya }\end{array}$ & $\begin{array}{l}\text { untuk tempat menyimpan } \\
\text { irisan tembakau }\end{array}$ \\
\hline 5. & $\begin{array}{l}\text { Irik kalo } \\
\text { [irIg kalo] }\end{array}$ & $\begin{array}{l}\text { anyaman berbentuk } \\
\text { bundar dengan pinggiran }\end{array}$ & $\begin{array}{l}\text { berfungsi untuk menyaring } \\
\text { santan }\end{array}$ \\
\hline 6. & $\begin{array}{l}\text { Kursi petung } \\
\text { [kUrsi p|tUG } \\
\text { ] }\end{array}$ & $\begin{array}{l}\text { Kursi santai dengan } \\
\text { kerangka terbuat dari } \\
\text { bambu utuh dengan jenis } \\
\text { tertentu, yaitu bambu } \\
\text { petung dan anyaman } \\
\text { untuk tempat duduknya } \\
\text { menggunakan bahan kulit } \\
\text { bamboo }\end{array}$ & $\begin{array}{l}\text { Tempat duduk untuk } \\
\text { bersantai di teras rumah }\end{array}$ \\
\hline 7. & $\begin{array}{l}\text { Tudung saji } \\
\text { [tudUG saji ] }\end{array}$ & $\begin{array}{l}\text { Anyaman bambu } \\
\text { berbentuk bundar atau } \\
\text { persegi empat. }\end{array}$ & $\begin{array}{l}\text { Tudung saji berfungsi untuk } \\
\text { menutup sajian makanan di } \\
\text { meja makan }\end{array}$ \\
\hline
\end{tabular}




\begin{tabular}{|c|c|c|c|}
\hline 8. & $\begin{array}{l}\text { krenjang } \\
\text { buah } \\
\text { [kr|njaG } \\
\text { buah] }\end{array}$ & $\begin{array}{l}\text { Keranjang dengan } \\
\text { berbagai macam bentuk, } \\
\text { bundar segi empat, yang } \\
\text { terbuat dari anyaman } \\
\text { bambu tipis yang } \\
\text { berfungsi untuk wadah } \\
\text { buah. Bentu kranjang } \\
\text { buah pada masa sekarang } \\
\text { sudah dibentuk } \\
\text { menyerupai wadah buah } \\
\text { modern }\end{array}$ & $\begin{array}{l}\text { Untuk tempat menyajikan } \\
\text { buah-buahan }\end{array}$ \\
\hline 9. & $\begin{array}{l}\text { Krenjang } \\
\text { pincuk } \\
\text { [Kr|njang } \\
\text { pincU?] }\end{array}$ & $\begin{array}{l}\text { keranjang dari anyaman } \\
\text { bambu kecil-kecil seperti } \\
\text { lidi yang berbentuk } \\
\text { bundar menyerupai } \\
\text { piring. }\end{array}$ & $\begin{array}{l}\text { Kranjang pincuk berfungsi } \\
\text { untuk alas pincuk (tempat } \\
\text { makan nasi yang terbuat } \\
\text { dari daun pisang) }\end{array}$ \\
\hline 10. & $\begin{array}{l}\text { kranjang } \\
\text { koran } \\
\text { [kr|njang } \\
\text { koran] }\end{array}$ & $\begin{array}{l}\text { karanjang yang terbuat } \\
\text { dari anyaman bambu } \\
\text { dengan bentuk } \\
\text { menyerupai tas tanpa } \\
\text { tutup dan diberi kaki. }\end{array}$ & $\begin{array}{l}\text { berfungsi untuk meletakkan } \\
\text { koran }\end{array}$ \\
\hline 11. & $\begin{array}{l}\text { Krenjang } \\
\text { jajan } \\
{[\text { kr|njang }} \\
\text { jajan] }\end{array}$ & $\begin{array}{l}\text { kranjang yang terbuat } \\
\text { dari anyaman bambu tipis } \\
\text { dan halus berbentuk } \\
\text { menyerupai mangkok } \\
\text { besar berkaki. }\end{array}$ & $\begin{array}{l}\text { Kranjang jajan digunakan } \\
\text { untuk tempat menyajikan } \\
\text { kue-kue tradisional }\end{array}$ \\
\hline 12. & $\begin{array}{l}\text { Krenjang tisu } \\
{[\mathrm{kr} \mid \text { njang }}\end{array}$ & $\begin{array}{l}\text { anyaman bambu } \\
\text { berbentuk kubus atau } \\
\text { persegi panjang }\end{array}$ & $\begin{array}{l}\text { digunakan untuk tempat } \\
\text { tisu. }\end{array}$ \\
\hline
\end{tabular}

18| http://journal.unesa.ac.id/index.php/paramasastra 


\begin{tabular}{|l|l|l|l|}
\hline 13. & $\begin{array}{l}\text { tisu] } \\
\text { Krenjang } \\
\text { blonjo } \\
{[\text { kr|njang }} \\
\text { blOnjO] }\end{array}$ & $\begin{array}{l}\text { keranjang dari anyaman } \\
\text { bambu berbentuk tas } \\
\text { dengan pegangan. }\end{array}$ & $\begin{array}{l}\text { Krenjang blonjo berfungsi } \\
\text { untuk tempat membawa } \\
\text { barang belanjaan }\end{array}$ \\
\hline 14. & $\begin{array}{l}\text { Krenjang } \\
\text { sampah } \\
{[\text { kr|njang }} \\
\text { sampah }]\end{array}$ & $\begin{array}{l}\text { keranjang dari anyaman } \\
\text { bambu berbemtuk kotak } \\
\text { atau tabung }\end{array}$ & $\begin{array}{l}\text { Kenjang sampah digunakan } \\
\text { untuk tempat sampah }\end{array}$ \\
\hline
\end{tabular}

Pada tabel di atas, terdapat empat belas leksikon peralatan rumah tanga berbahan bambu yang berbentuk frasa, yaitu besek cebek, besek sabun, besek ros, besek gedhe, irik kalo, kursi petung, tudung saji, krenjang pincuk, krenjang buah, krenjang tisu, krenjang koran, krenjang jajan, krenjang blonjo, dan krenjang sampah. . Leksikon tersebut masih banyak digunakan dalam kehidupan sehari-hari masyarakat di Kabupaten Magetan, terutama masyarakat yang tinggal di pedesaan.Leksikon untuk mengungkap atau yang berhubungan dengan peralatan rumah tanga tersebut cukup memperkaya khasanah bahasa, khususnya yang berhubungan dengan peralatan berbahan bambu. Dari keempat belas leksikon berbentuk frasa tersebut sebagian sudah ada sejak dahulu dan sebagian leksikon tersebut muncul seiring dengan perkembangan budaya modern. Di antara leksikon peralatan rumah tangga berbahan bambu berbentuk frasa tersebut yang sudah ada sejak dahulu adalah besek cebek, besek sabun, besek ros, besek gedhe, irik kalo, krenjang pincuk, dan krenjang blonjo. Sedangkan leksikon peralatan rumah tangga yang muncul sebagai produk inovasi karena pengaruh budaya modern adalah kursi petung, tudung saji, krenjang buah, krenjang tisu, krenjang koran, dan krenjang jajan. 


\section{SIMPULAN}

Berdasarkan hasil temuan data yang terkumpul dari hasil analisis data, maka dapat disimpulkan bahwa setiap perkembangan dari suatu aspek kebudayaan selalu tercermin pada leksikonnya. Perkembangan dan berubahan yang terjadi pada peralatan rumah tangga berbahan bambu juga diiringi dengan perkembangan leksikon. Leksikon peralatan rumah tangga tradisional berbahan bambu dapat diklasifikasikan dalam beberapa bentuk, yaitu leksikon berstruktur monomorfemis, polimorfemis, bentuk ulang, dan ada juga leksikon yang berbentuk frasa. Leksikon yang ditemukan dalam data sebagian adalah leksikon yang sudah ada sejak dahulu dan sebagian adalah leksikon baru yang muncul seiring dengan perkembangan budaya zaman sekarang.

\section{DAFTAR PUSTAKA}

Baehaqie, Imam. 2013. Etnoliguistik Telah Teoretis dan Praktis. Surakarta: Cakrawala Media

Duranti, A. 1997. Linguistic Anthropology. Cambridge: Cambridge University Press.

Foley, W. A. 1997. Anthropological Linguistics: An Introduction.Oxford: Blackwell Publishers.

Koentjaraningrat. 1983. Kebudayaan, Mentalitas dan Pembangunan. Jakarta: PT Gramedia.

Koentjaraningrat. 1990. Sejarah Teori Antropologi. Jakarta: Penerbit Universitas Indonesia.

Mbete, A. M. 2004. "Linguistik Kebudayaan: Rintisan Konsep dan Beberapa Aspek Kajiannya", dalam Bawa, I.W. dan Cika, I.W (ed.), Bahasa dalam Perspektif Kebudayaan, halaman 16-32. Denpasar: Penerbit Universitas Udayana.

Palmer, G. B. 1996. Toward a Theory of Cultural Linguistics. Austin: University of Texas Press.

Sudaryanto. 1986. Metode Linguistik. Kedudukan Aneka Jenisnya dan Faktor Penentu wujudnya. Yogyakarta. Fakultas Sastra dan Kebudayaan Universitas Gajah Mada.

Wierzbicka, A. 1991. Cross-Cultural Pragmatics, The Semantics of Human Interaction. New York: Mouton de Gruyter. 